Review

\title{
Hereditary and Sporadic Forms of A $\beta$-Cerebrovascular Amyloidosis and Relevant Transgenic Mouse Models
}

\section{Samir Kumar-Singh ${ }^{1,2,3}$}

1 Neurodegenerative Brain Diseases Group, VIB Department of Molecular Genetics, University of Antwerp, Antwerpen - CDE, Universiteitsplein 1, B-2610, Antwerpen, Belgium; E-Mail: samir.kumarsingh@molgen.vib-ua.be; Tel. +3232651002; Fax: +3232651012

2 Laboratory of Neurogenetics, Institute Born Bunge, University of Antwerp, Antwerpen, Belgium

3 University of Antwerp, Antwerpen, Belgium

Received: 16 January 2009; in revised form: 14 April 2009 / Accepted: 20 April 2009 /

Published: 23 April 2009

\begin{abstract}
Cerebral amyloid angiopathy (CAA) refers to the specific deposition of amyloid fibrils in the leptomeningeal and cerebral blood vessel walls, often causing secondary vascular degenerative changes. Although many kinds of peptides are known to be deposited as vascular amyloid, amyloid- $\beta$ (A $\beta$ )-CAA is the most common type associated with normal aging, sporadic CAA, Alzheimer's disease (AD) and Down's syndrome. Moreover, A $\beta$-CAA is also associated with rare hereditary cerebrovascular amyloidosis due to mutations within the $A \beta$ domain of the amyloid precursor protein (APP) such as Dutch and Flemish APP mutations. Genetics and clinicopathological studies on these familial diseases as well as sporadic conditions have already shown that CAA not only causes haemorrhagic and ischemic strokes, but also leads to progressive dementia. Transgenic mouse models based on familial AD mutations have also successfully reproduced many of the features found in human disease, providing us with important insights into the pathogenesis of CAA. Importantly, such studies have pointed out that specific vastopic $A \beta$ variants or an unaltered $A \beta 42 / A \beta 40$ ratio favor vascular $A \beta$ deposition over parenchymal plaques, but higher than critical levels of $A \beta 40$ are also observed to be anti-amyloidogenic. These data would be important in the development of therapies targeting amyloid in vessels.
\end{abstract}

Keywords: Alzheimer's disease; cerebrovascular amyloidosis; CAA; dense-core plaques; senile plaques; amyloid $\beta$ protein; transgenic mice; pathogenesis; therapy. 


\section{Introduction}

Accumulation of amyloid $\beta$-protein $(A \beta)$ in the cerebral vasculature is a common pathological feature of Alzheimer's disease (AD) and cerebral amyloid angiopathy (CAA) [1,2,3]. Many biochemically distinct types of amyloid have been reported to deposit in cerebral vessels such as $A \beta$, cystatin-C (Icelandic CAA), transthyretin, gelsolin, prion protein, and the ABri and ADan subunits in familial British and familial Danish dementia [3]. However, CAA caused by A $\beta$ is the most common form of sporadic CAA and also occurs in AD patients [1,2,3].

$\mathrm{A} \beta$ is a 40 to 42 aminoacid peptide derived from the amyloid precursor protein (APP), a type 1 transmembrane glycoprotein, through sequential proteolysis by $\beta$-secretase and $\gamma$-secretase/presenilin complex. A prior cleavage by $\alpha$-secretase prevents the generation of full-length $A \beta$ and generates $\mathrm{p} 3$ (Figure 1). $A \beta$ has a pronounced propensity to form fibrillar aggregates, and the longer, more hydrophobic $A \beta 42$ is also more prone to form fibrils than the shorter $A \beta 40$ isoform. According to the amyloid cascade hypothesis, $A \beta$ deposition is causative for the pathogenesis of AD [4]. One of the most convincing evidence to support this premise is identification of mutations in APP near the $\beta$ - or $\gamma$-secretase cleavage site or in the presenilin gene causing familial forms of AD that increase the absolute or relative levels of $A \beta 42$ [4]. While in these familial forms $A \beta$ is also deposited in vessels, the most severe CAA is observed in patients with APP mutations that lie within the A $\beta$ domain such as Flemish, Dutch, Italian, Arctic, and Iowa, amongst others (Figure 1).

\section{Clinical and Pathological Consequences of CAA}

$\mathrm{A} \beta \mathrm{CAA}$ (henceforth $\mathrm{CAA}$ ) is shown to affect leptomeningeal and cortical arteries, arterioles, capillaries, venules and veins in both sporadic and familial CAA, and in almost all AD patients [5,6,1]. Depending on the predominant type of vessel involved, two types of CAA have been distinguished: CAA-type 1 and type 2. CAA-type 1 affects meningeal and cortical arterioles, capillaries, veins and venules while CAA-type 2, also called large-vessel CAA, affects meningeal and cortical vessels but has a tendency to spare cortical capillaries [7]. In CAA-type I, A $\beta$ frequently permeates the glioadventitial junction of capillaries and small arterioles and extends into the parenchyma as "dyshoric angiopathy" [5,8]. Also, depending on the level of vascular involvement, a simple 3-tiered grading system of mild, moderate, and severe CAA has been proposed [9]. In "mild" CAA, focal A $\beta$ deposition restricted to the tunica media occurs in an otherwise normal vessel. In "moderate" CAA, A $\beta$ deposition involves the entire thickness of tunica media, thus completely replacing the smooth muscle cell layer. No evidence of recent or old blood leakage is found. In "severe" CAA, A $\beta$ deposition involves other vascular wall layers and the vascular architecture is severely disrupted with secondary changes such as microaneurysmal dilatation, fibrinoid necrosis, and vessel rupture $[9,10,11]$. 
Figure 1. Schematic representation of amyloid precursor protein (APP), positions of the A $\beta$ sequence, transmembrane domain of APP (Tm), and sites of $\alpha$-, $\beta$ - and $\gamma$-secretase cleavage.

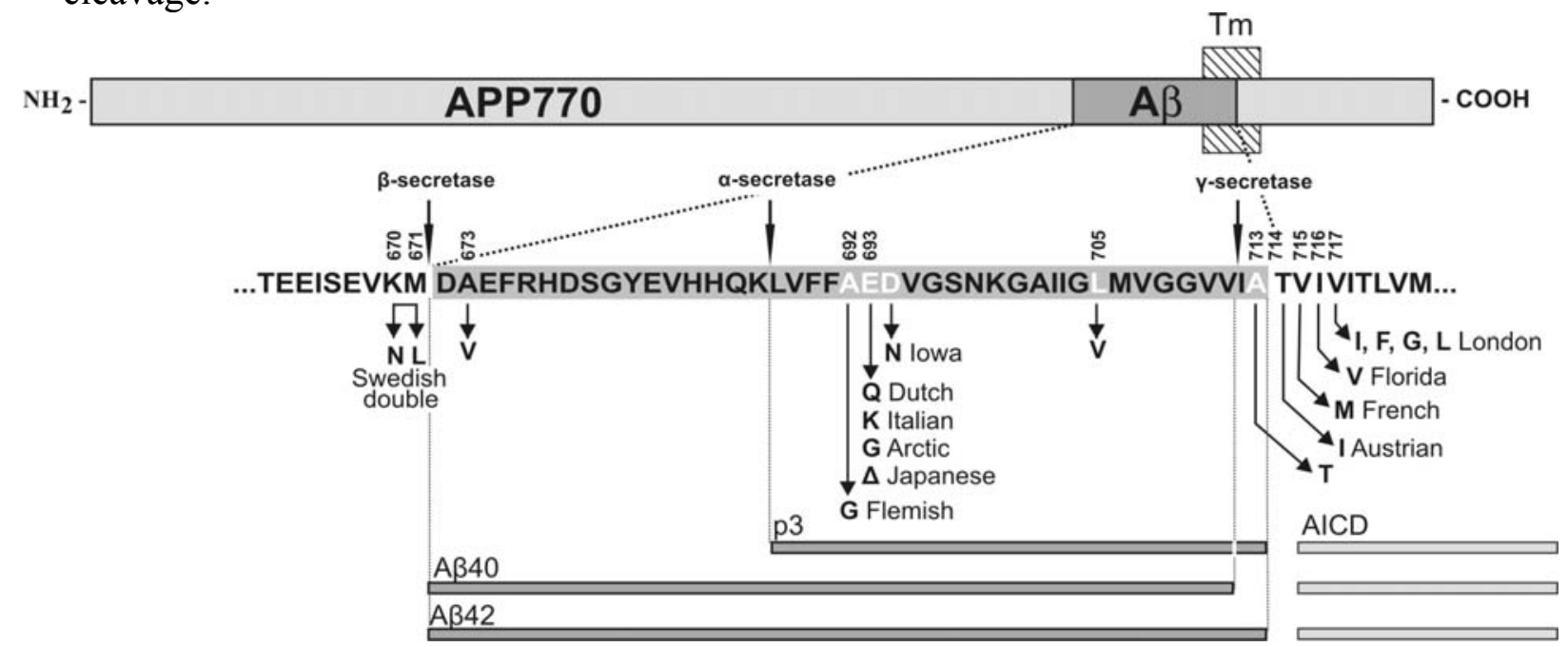

$\mathrm{NH}_{2}$ and $\mathrm{COOH}$ indicate the $\mathrm{N}$-terminus and $\mathrm{C}$-terminus of the protein. $\mathrm{A} \beta$ sequence is enlarged below. The constitutive proteolytic cleavage by $\alpha$ - and $\gamma$-secretases leads to the formation of the short $\mathrm{p} 3$ peptide and processing by $\beta$ - and $\gamma$-secretases leads to $\mathrm{A} \beta 40$ and $\mathrm{A} \beta 42$ peptides with a consecutive release of a C-terminal APP intracytoplasmic domain (AICD). Also shown are AD/CAA-causing pathogenic amino acid substitutions within APP (see also Table 2 and visit www.molgen.ua.ac.be/ADMutations for a complete and updated list of these mutations).

CAA also has important and sometimes fatal pathological consequences. One of the most wellrecognized complications of CAA is spontaneous, often recurrent, intracerebral haemorrhage, usually involving the cortex and/or subcortical white matter $[12,13,14,9,15,16]$. Secondly, CAA also increases the risk of cerebral infarction, especially in the watershed areas, and is frequently associated with ischaemic leucoencephalopathy $[17,18,19]$. Thirdly, CAA has also been associated with progressive dementia in sporadic CAA patients [20,21,22]. Even in patients devoid of any AD pathology, CAA has been significantly associated with the presence of clinical dementia [23,22]. Interestingly, CAA-type I has been shown to be more closely related to AD pathology than large-vessel CAA [1,24], and increased perivascular phosphorylated tau as well as perivascular inflammation is observed with this type of CAA (see later).

\section{APP Mutations within the Aß Sequence Associated with Cerebrovascular Amyloidosis}

The genetics of CAA is tightly linked to that of AD. However, research conducted on CAA has been more rewarding in improving our understanding of the biochemistry and molecular genetics of $A \beta$ amyloidogenesis. Not only was $A \beta$ peptide identified first from amyloid deposited in vascular walls in AD and Down's syndrome patients [25], but the APP mutations were also identified for the first time in a familial form of CAA called hereditary cerebral haemorrhage with amyloidosis - Dutch type (HCHWA-D). HCHWA-D is an autosomal dominant form of CAA characterized by recurrent haemorrhages due to extensive $A \beta$ deposition in cerebral blood vessel walls and diffuse amyloid plaques but absence of dense-core senile plaques or neurofibrillary tau pathology $[26,27,28]$ (Table 1). 
HCHWA-D patients were identified to carry Dutch APP mutation at codon 693 (APP 770 isoform) replacing a glutamate $(\mathrm{E})$ by a glutamine $(\mathrm{Q})[29,30]$.

Table 1. Extracellular cerebral amyloid deposits commonly present in familial and sporadic A $\beta$ CAA and AD patients and transgenic mouse models.

\begin{tabular}{|l|l|}
\hline CAA & $\begin{array}{l}\text { Cerebral amyloid angiopathy; pathological changes occurring in cerebral blood } \\
\text { vessels caused by deposition of amyloid protein of different origins, but here } \\
\text { due to A } \beta .\end{array}$ \\
\hline $\begin{array}{l}\text { Dense-core } \\
\text { plaques }\end{array}$ & $\begin{array}{l}\text { Also referred to as "neuritic", "senile", "classic", or "mature" plaques. The } \\
\text { central compact dense-core is surrounded by a corona of diffuse plaque. The } \\
\text { corona contains predominantly A } \beta 42 \text { and is ThS-negative. The core is ThS- } \\
\text { positive. Almost always associated with proximate phospho-tau pathology. }\end{array}$ \\
\hline Dense plaques & $\begin{array}{l}\text { ThS-positive compact amyloid without the corona of diffuse plaques. Major } \\
\text { compact plaque type in transgenic mouse models. Biochemically resembles } \\
\text { cores of the dense-core plaques. In this review, also sometimes used to include } \\
\text { dense-core plaques. }\end{array}$ \\
\hline $\begin{array}{l}\text { Diffuse } \\
\text { plaques }\end{array}$ & $\begin{array}{l}\text { Loosely arranged fibrils that are usually ThS-negative. Best recognized with } \\
\text { immunohistochemistry and are constituted predominantly of A } \beta 42 . \text { Are not } \\
\text { commonly associated with proximate phospho-tau pathology. }\end{array}$ \\
\hline
\end{tabular}

Soon after, the Flemish APP mutation replacing a glycine (G) by an alanine (A) at the adjacent codon 692 was identified in another Dutch family suffering from presenile dementia and cerebral haemorrhage inherited in an autosomal dominant pattern [31]. Interestingly, clinical phenotypes in Flemish APP carriers overlapped to the extent that cerebral haemorrhages were reported in offspring of patients having dementia while patients with strokes had offspring developing progressive dementia [32,33]. Flemish APP carriers were also shown to have definitive AD with numerous, large senile plaques accompanied by a very severe degree of leptomeningeal and parenchymal CAA [34,33,35]. Moreover, in contrast to HCHWA-D patients, Flemish APP carriers have neurofibrillary tau pathology [33,34] (Figure 2).

Subsequently, other APP mutations within the A $\beta$ sequence were also identified - such as "Italian" (E693K), "Arctic" (E693G), "Japanese" (E6934), "Iowa" (D694N) and L705V APP mutations (Table 2; www.molgen.ua.ac.be/ADMutations). The pathology associated with these mutations resembled either Dutch or Flemish APP pathology by having a pure CAA/cerebral haemorrhage or a mixed AD CAA/cerebral haemorrhage phenotype. For instance, Italian APP and APP L705V mutation resembles the Dutch APP carriers with a predominant CAA with or without recurrent haemorrhages [36,37]. Also, similar to Dutch APP mutation, neurofibrillary tangles (NFT) were absent in APP L705V carriers [37] or were mild and restricted to the archicortex as in the Italian APP carriers [36]. The Arctic and Iowa APP carriers resemble the Flemish APP carriers by having a mixed AD/ severe CAA phenotype, although haemorrhagic strokes are not observed [38,39,40,41]. Moreover, consistent to an AD phenotype, parenchymal, ringlike plaques are observed in the Arctic APP carriers [39]. In addition 
to these APP mutations near the $\alpha$-secretase site, intragenic A $\beta$ mutations are also reported near the $\beta$ and $\gamma$-secretase site of APP. For instance, APP A713T mutation near the $\gamma$-secretase site reportedly leads to progressive dementia and multiple strokes, and pathological studies confirm AD with severe CAA with multiple infarcts in brain [42]. Similarly, the APP A673V mutation near the $\beta$-secretase site of APP has been shown to be associated with AD type of dementia and, consistent with an autosomal recessive pattern of inheritance, is pathogenic only in a homozygous state [43]. Neuropathological data for APP A673V carriers is not yet available [43].

Figure 2. Spectrum of disease from primarily hereditary amyloidosis of Dutch and Flemish type to familial forms of Alzheimer's disease (AD) and to mouse models of AD.
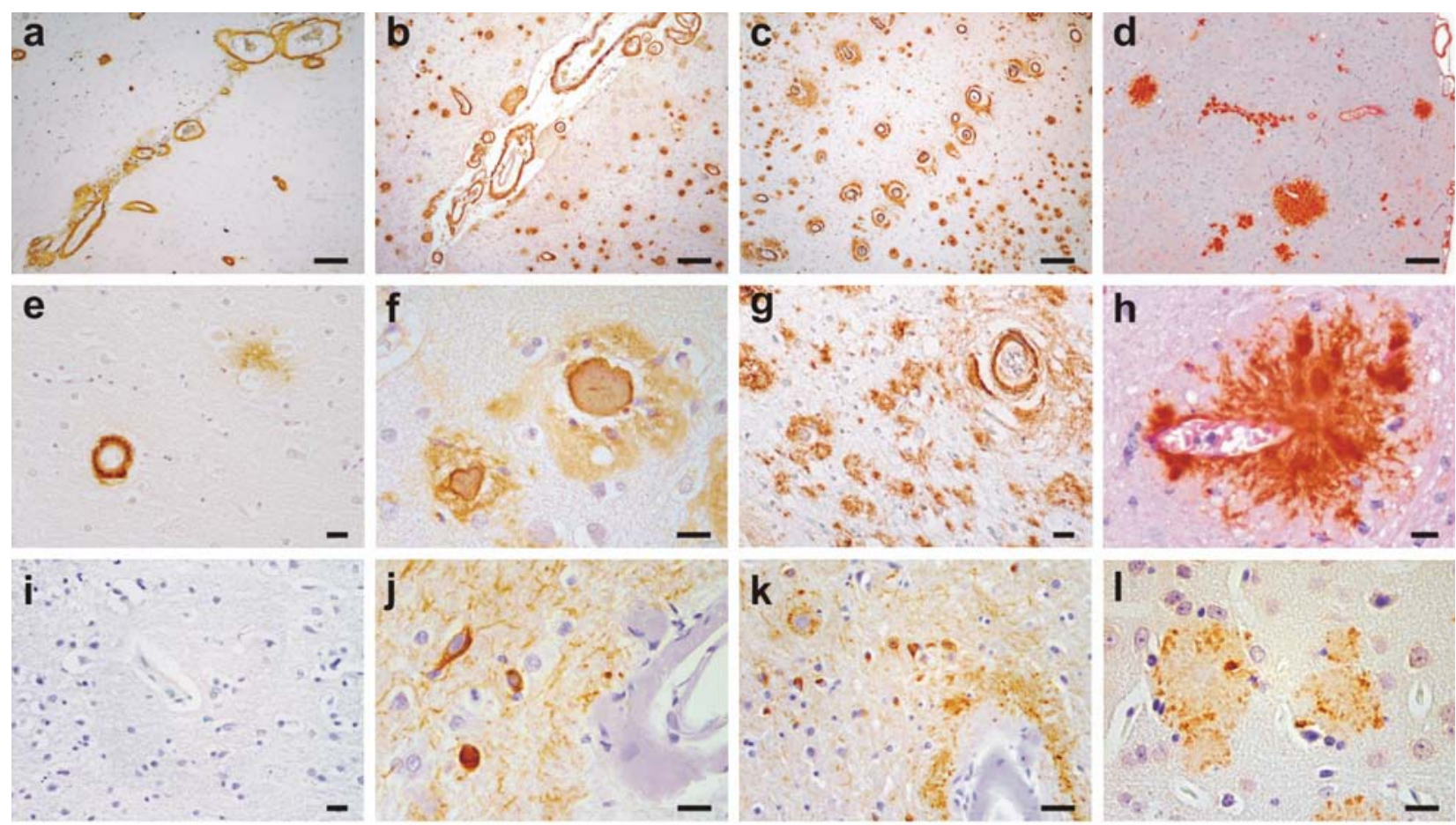

The upper and middle panels depict $\mathrm{A} \beta$ staining with monoclonal antibody 4G8 in an HCHWA-D (E693Q) patient with CAA (a, e), a Flemish APP carrier with both CAA and senile plaques (b, f); a presenilin (PS)-1 L282V AD patient with senile plaques and prominent CAA (c, g), and Tg2576 mouse model with parenchymal plaques and CAA $(\mathrm{d}, \mathrm{h})$. The lower panel is phosphorylated tau staining (monoclonal antibody AT8) in temporal cortical regions of the same patients ( $\mathrm{i}-\mathrm{k}$ ); or ubiquitin staining for Tg2576 (1). Note that HCHWA-D brains lacks dense-core senile plaque or phospho-tau pathology but do show diffuse amyloid plaques (e and i). Flemish APP and PS1 L282V carriers have phosphorylated tau immunostaining in neurofibrillary tangles, ballooned neurites and neuropil threads $(\mathrm{j}-\mathrm{k})$. Sections are immunostained with avidin-biotin complex/horseradish peroxidase system and color developed with 3'3'diaminobenzidine. Scale bars in $\mathrm{a}-\mathrm{d}, 200 \mu \mathrm{m}$; and $\mathrm{e}-1,20 \mu \mathrm{m}$. 
Table 2. Clinicopathological spectrum for APP mutations within A $\beta 1-43$ coding sequence.

\begin{tabular}{|c|c|c|c|c|c|c|}
\hline $\begin{array}{l}\text { APP } \\
\text { Codon* }\end{array}$ & Substitution & $\begin{array}{l}\text { Position } \\
\text { within } \\
\text { A } \beta \\
\end{array}$ & $\begin{array}{l}\text { Proximity } \\
\text { to } \\
\text { secretases }\end{array}$ & Nickname & Disease & References \\
\hline 673 & Ala $\rightarrow$ Val & $\mathrm{A} 2 \mathrm{~V}$ & $\beta$-secretase & & & [43] \\
\hline 692 & Ala $\rightarrow$ Gly & $\mathrm{A} 21 \mathrm{G}$ & & Flemish & $\begin{array}{l}\mathrm{AD} / \text { Cerebral } \\
\text { haemorrhage }\end{array}$ & {$[31,33]$} \\
\hline 693 & Glu $\rightarrow$ Gln & E22Q & & Dutch & $\begin{array}{l}\text { Cerebral } \\
\text { haemorrhage }\end{array}$ & {$[29,44]$} \\
\hline 693 & Glu $\rightarrow$ Lys & E22K & & Italian & $\begin{array}{l}\text { Cerebral } \\
\text { haemorrhage }\end{array}$ & {$[36]$} \\
\hline 693 & Glu $\rightarrow$ Gly & E22G & $\alpha$-secretase & Arctic & $\begin{array}{l}\mathrm{AD} / \text { severe CAA } \\
\text { but no strokes }\end{array}$ & {$[38,39]$} \\
\hline 693 & Glu-->Del & $\mathrm{E} 22 \Delta$ & & Japanese & $\begin{array}{l}\text { AD; pathology } \\
\text { unavailable }\end{array}$ & [45] \\
\hline 694 & Asp $\rightarrow$ Asn & $\mathrm{D} 23 \mathrm{~N}$ & & Iowa & $\begin{array}{l}\mathrm{AD} / \text { severe } \mathrm{CAA} \\
\text { but no strokes }\end{array}$ & {$[40,41]$} \\
\hline 705 & Leu $\rightarrow$ Val & L34V & & - & Severe CAA & [37] \\
\hline 713 & Ala $\rightarrow$ Thr & $\mathrm{A} 42 \mathrm{~T}$ & $\gamma$-secretase & - & $\begin{array}{l}\mathrm{AD} / \text { Cerebral } \\
\text { haemorrhage }\end{array}$ & [42] \\
\hline 714 & Thr $\rightarrow$ Iso & T43I & & Austrian & $\mathrm{AD}$ & [46] \\
\hline
\end{tabular}

*Numbered according to the largest APP transcript APP770.

It is clear that APP mutations lying within the $A \beta$ sequence cause pathology by mechanisms distinct from those involving the other APP or presenilin (PS) mutations that cause AD. For instance, the ADcausing mutations in APP or PS were shown to alter APP processing in a manner that increases the absolute or relative levels of $A \beta 42$, the more fibrillogenic $A \beta$ species [47]. Consider, for example, APP Swedish double mutation (K670N/M671L) that leads to increased absolute levels of A $\beta 42$ along with $\mathrm{A} \beta 40$ (without changing the A $\beta 42 / \mathrm{A} \beta 40$ ratio), while $\gamma$-secretase site APP mutations increase the relative levels of $A \beta 42$ by increasing the ratio of $A \beta 42 / A \beta 40$ [4]. Similarly, PS1 and PS2 mutations also increased the relative levels of $A \beta 42$ by increasing the ratio $A \beta 42 / A \beta 40$ [4]. On the other hand, mutations within the $A \beta$ sequence were predicted not only to alter the processing of APP and/or increasing total $A \beta$ production, but were also thought to alter the aggregation properties of the resulting mutant $A \beta$ peptide.

Initial studies seemingly supporting this hypothesis, however, were not completely clear. This was because the Dutch APP peptide showed highly accelerated fibrillogenic kinetics, increased stability, and higher in vitro toxicity; while the kinetics of the Flemish $A \beta$ peptide were even slower than the wild-type $A \beta$ and the peptide also did not show any increased toxicity to cells in vitro $[48,49,50,51]$. This obviously contrasted sharply with the clinicopathological consequences as Flemish APP carriers had clinical and pathological AD while the Dutch APP patients although had diffuse type of A $\beta$ deposits, but lacked neuritic, senile plaques characteristic of AD. Subsequent in vitro studies, however, showed that compared to wild type and Dutch $A \beta$, Flemish $A \beta$ was most toxic to differentiated SHSY5Y cells in the early stages of aggregation when $A \beta$ fibrils were not observed [51]. In the late stages of aggregation, the Dutch peptide remained the most toxic $A \beta$ species, suggesting that $A \beta$, at least 
under in vitro conditions, is neurotoxic in an initial phase due to its soluble oligomeric or other early toxic $A \beta$ intermediate(s), which was distinct from the late neurotoxicity incurred by larger aggregated assemblies of $A \beta[51,52]$. Moreover, it was also suggested that the cytotoxic potential of $A \beta$ lies in their ability to form extensive fibrils directly on the cell surface, as preaggregation of $A \beta$ abolished its toxic effect on cultured cells [53]. Thus, Dutch A $\beta$ once released from the sites of generation, aggregates almost instantaneously in the parenchymal matrix as non-neuritic diffuse plaques $[51,54]$. The Flemish APP, on the other hand, not only leads to increased A $\beta$ production due to an increased activity of $\beta$-site APP-cleaving enzyme-2 [55], but also slowly fibrillizing mutant A $\beta$ diffuses more efficiently to aggregate as one of the largest dense-core amyloid deposits known in AD. Subsequently, it was also shown that most of the dense-core amyloid plaques observed in the Flemish APP carriers develop in close association with vessel walls [33], perhaps due to entrapment of $A \beta$ in the vascular clearance routes [56,57]. Further observations in Flemish APP carriers showed that CAA-related plaques could also trigger accumulation of tau-immunoreactive dystrophic neurites in the surrounding neuropil similar to dense-core plaques [33] (Figure 2). Vessel association of dense-core plaques might not be unique to Flemish APP carriers as suggested by a recent study showing a significant association between dense-core plaques and Prussian blue-labelled haeme deposits in sporadic AD and Down's syndrome patients, and even proposing that dense-core plaques are sites of older microhaemorrhages [58].

Subsequent studies on other APP mutations within the A $\beta$ sequence identified similar or additional disease mechanisms. Consider for example, the Italian peptide showing increased propensity to make fibrils and peptide-mediated pathogenic effects similar to the Dutch peptide [59,60]. As a matter of fact, substitutions at APP 693 codon that cause either a loss of charge (E22Q; Dutch APP) or a change of charge (E22K; Italian APP) show increased binding to and degeneration of cerebrovascular smooth muscle cells [59] and, not surprisingly, both of them lead to CAA/ haemorrhagic strokes. On the other hand, complete deletion of APP 693 codon as in Japanese APP shows altered aggregation property of enhanced oligomerization but no fibrillization [45]. This is similar to the Arctic APP variant that also increases the propensity of protofibril formation without increasing the rate of fibril formation or the production of A 3 [38]. And lastly, the Iowa APP carriers that resemble Flemish and Dutch APP carriers show cytotoxicity and aggregation properties that lie between those caused by the Flemish and Dutch $A \beta$ peptides [60]. Interestingly, Flemish, Dutch, Italian, Arctic, and Japanese $A \beta$ variants are also shown to be more resistant to proteolytic degradation $[61,45,62]$. Recent data also suggest that Dutch, Italian, and Iowa preferably assemble in the presence of GM3 ganglioside [63] while their clearance across the blood-brain barrier (BBB) might be reduced as shown for Dutch/Iowa mutant $[64,65]$. It remains to be shown that oligomers of the variant $A \beta$ that are associated with $A D$ changes are more synaptotoxic than wild type $A \beta$ oligomers [45].

\section{Other Genetic Risk Factors for CAA}

Copy number variations of the APP gene also seem to be important for development of CAA. For instance, Down's syndrome patients who have three copies of APP, have CAA as young as 30 years and the severity of CAA increases with age [66]. Down's syndrome patients are also reported to have strokes $[67,68,69]$. Similarly, duplications of the APP locus in certain French and Dutch families or 
populations demonstrate an autosomal dominant $\mathrm{AD}$ and/or lobar cerebral haemorrhage with prominent CAA [70,71]. APP duplications increase the absolute amounts of both A $\beta 42$ and A $\beta 40$ (without changing the ratio), an important factor proposed to lead to $A \beta$ deposition in vessel walls $[33,72]$. Although uncommon, a predominant CAA is also observed in select PS1 mutations like Q184D and L282V, amongst others [73,74,75,76,77]. The best studied PS2 mutation, N141I, has also been reported to lead to haemorrhagic strokes in Volga-German family [78]. It remains to be shown whether some of these mutations, especially those occurring after codon 200 [79], might not alter A $\beta 40$ production as has been shown for the majority of PS mutations $[80,81]$.

Specific apolipoprotein E (APOE) alleles are not only a strong risk factor for development of AD, but are also linked to development of CAA and strokes. CAA related to capillaries and smaller arterioles is observed to be closely associated with ApoE- $\varepsilon 4$, but not ApoE- $\varepsilon 2$ [7]. ApoE- $\varepsilon 4$ is also independently associated with increased vascular $\mathrm{A} \beta$ deposition in large-vessel CAA leading to strokes $[82,83,84]$. On the other hand, ApoE- $\varepsilon 2$ appears to promote degenerative changes in the amyloid-laden vessel wall and is a cause of stroke independent of $A \beta$ deposition [85,86]. Anecdotal examples of individuals homozygous for the APOE- $\varepsilon 4$ allele that have a predominant CAA or a CAA-related pathology are also described [23]. Lastly, candidate genes involving A $\beta$ degradation pathways have also been implicated in the development of CAA [87]. For instance, a polymorphism in the Neprilysin gene has been shown to be associated with CAA [88]. For many of these candidate genes, knockout mouse models have been made as discussed in the next section.

\section{Mouse Models of Cerebrovascular Amyloidosis}

Most disease models are based on inherited forms of disease that although less common than the sporadic forms, are clinically indistinguishable from each other. The first attempts to model the archetypal Dutch and Flemish APP cerebral amyloidosis in mice did not show amyloid till at least 18 months of age [89,90], however, recent experiments have successfully created Dutch APP mice [91]. At $\approx 25$ months of age, APP Dutch mice demonstrate extensive CAA, smooth muscle cell degeneration and haemorrhages - features that are typical of HCHWA-D [91]. Similarly, transgenic mice expressing Dutch/Iowa mutant A $\beta$ (Tg-SwDI) at levels below those of endogenous mouse APP have also been established that robustly deposit $A \beta$, particularly in the cerebral microvasculature, from 3 months of age $[92,93]$. However, because mutant $A \beta$ is expected to have altered biophysical properties, any direct extrapolation to sporadic CAA has to be made with caution.

Interestingly, mice overexpressing wild type A $\beta$ such as APP Swedish mice (APP/Sw; e.g., Tg2576 and APP23 mice), or APP London mice, develop CAA fairly early and have been used as a valid model for CAA $[94,95,96]$ (www.alzforum.org/res/com/tra). Importantly, APP/Sw mice with unaltered relative ratios of $A \beta 42 / A \beta 40$ are even more representative of sporadic $C A A / A D$ and have been employed in several studies. In principle, these mouse models have provided support for many important concepts in our understanding of cerebral amyloidosis including $A \beta$ deposition in vessel walls, as summarized below:

(1) Mouse models have given a definitive view that $A \beta 42$ is essential for $A \beta$ deposition not only in parenchyma but also in vessels. When $\mathrm{APP} / \mathrm{Sw}$ mice (producing both $\mathrm{A} \beta 40$ and $\mathrm{A} \beta 42$ ) are bred with mice expressing mutant PS1 (that increases brain $\mathrm{A} \beta 42 / \mathrm{A} \beta 40$ ratio), the crossbred mice 
have drastically increased amyloid deposition in parenchyma and vessels compared to single transgenic controls $[97,98]$. These APP/PS1 mice also have a higher number but smaller sizes of amyloid deposits most likely due to the extra "seeds" provided by A $\beta 42$ [99]. A similar crossbreeding of APP Dutch mice with mice expressing AD-related PS1 G384A mutation also increases amyloid depositions and shifts the pathology from vascular to the parenchymal compartment [91]. The premise that $A \beta 42$ is essential for $A \beta$ deposition is also neatly answered by BRI-A $\beta 40$ and BRI-A $\beta 42$ mice that produce only $A \beta 40$ or $A \beta 42$ [100]. In these mice, a fusion construct is utilized wherein the carboxyl terminus sequence of BRI protein, involved in amyloid deposition in familial British and Danish dementia, is replaced by a sequence encoding either $A \beta 40$ or $A \beta 42$. A proteolytic cleavage of this fusion protein at a furin cleavage site immediately preceding $A \beta$ results in high-levels of $A \beta 40$ or $A \beta 42$ secretion. While BRI-A $\beta 40$ mice expressing high levels of $A \beta 40$ do not develop overt amyloid pathology, the BRI-A $\beta 42$ mice line expressing lower levels of $A \beta 42$ develop all types of brain amyloid deposits including CAA [100]. Crossbreeding of BRI-A $\beta 42$ mice with Tg2576 mice again leads to a massive increase in amyloid deposition. These data establish that A $\beta 42$ is essential for amyloid deposition in the parenchyma and also in vessels.

(2) Mouse models have also supported a "protective" role of A $\beta 40$ in plaque deposition and therefore in $\mathrm{AD}$ pathology, especially when the levels of $\mathrm{A} \beta 40$ exceed a critical level. The initial data to support a protective role of $A \beta 40$ came from in vitro studies where $A \beta 40$ was shown to directly interfere with $A \beta 42$ aggregation by delaying the $A \beta 42$-mediated nucleation step at an early stage in the fibrillogenesis process [101]. More recently, $\gamma$-secretase site APP mutations, like the Austrian (T714I) and French (V715M) mutations, have also been shown to cause a drastic decrease in A $\beta 40$ production [102,103]. For instance, Austrian APP reduces $\mathrm{A} \beta 40$ by $\approx 80 \%$ and because $\mathrm{A} \beta 40$ is the major physiologically produced peptide $(\approx 9$ times more than $A \beta 42)$, a sharp reduction in total $A \beta$ also occurs [102,104]. A similar decrease in absolute A $\beta 40$ levels has also been shown for a number of clinical PS mutants [80,81] and interestingly, age-of-onset of PS1-linked AD not only correlates inversely with A $\beta 42$ but also directly with A $\beta 40$ levels [80,105]. Further studies on mouse models have also provided compelling data to support the premise that $A \beta 40$ is anti-amyloidotic. First, results from transgenic mice expressing wild-type and various mutant forms of APP suggest that increased A 340 levels reduce amyloid deposition [106]. Secondly, at least two independent studies utilizing knockin PS familial AD mutations crossbred with Tg2576 mice show a greatly accelerated plaque pathology accompanied by decreased production of $A \beta 40$ without an increase in secreted brain A $\beta 42$ levels $[107,108]$. Similarly, BRI-A $\beta 40$ mice crossbred with either BRI-A $\beta 42$ or Tg2576 mice show greatly reduced brain amyloid deposition compared to singly transgenic BRI-A $\beta 42$ or Tg2576 mice [100]. These data all suggest that in the absence of $\mathrm{A} \beta 42$, the clearance of $A \beta 40$ is very high, and depending upon the critical levels of $A \beta 42, A \beta 40$ might even be anti-amyloidotic [72].

(3) Recent work on knockout and transgenic mice has provided evidence that $A \beta$ is cleared from brain by mechanisms involving microglial uptake, degradation by cellular or extracellular proteases, as well as by clearance through vascular route. For instance, in vivo imaging of live mice has shown that $A \beta$ is not only taken up by microglia but astrocytes also play a direct role 
in degradation of $A \beta$ [109]. Secondly, knockout mouse models have supported data of A $\beta$ degradation by brain proteases such as neprilysin, insulin-degrading enzyme (IDE), endothelinconverting enzymes-1 and -2 , and matrix metalloproteinase-2 and -9 [110]. Consider, for example, neprilysin homozygous knockout mice expressing mutant APP and showing an expectedly higher burden of brain amyloid including CAA [111]. Thirdly, studies on mouse models have demonstrated that $\mathrm{A} \beta$ that cannot be locally degraded has the potential to diffuse away from the site of production. Non-transgenic brain tissue grafted in APP23 hosts develop both diffuse and congophilic amyloid plaques [112]. And finally, experimental studies in mice have shown that diffusible $\mathrm{A} \beta$ is transported directly across the BBB into the blood, mediated by low density lipoprotein receptor-related protein-1 (LRP-1)/ $\alpha 2$-macroglobulin and ApoE $[113,57]$. Mouse models of mutant $A \beta$ have also shown that some of these mutant $A \beta$ such as the Dutch/Iowa mutants could be deficient in its clearance across the BBB explaining the robust CAA seen in these mutation carriers (Deane et al., 2004; Davis et al., 2006). Studies on rodents also support a second vessel-related $\mathrm{A} \beta$ clearance route along the periarterial spaces $[56,113,114]$. Exogenous tracer studies in rats show that tracers injected into the parenchyma of grey matter in the rat brain drain along perivascular spaces around leptomeningeal arteries to the base of the brain, pass through the cribriform plate and, via nasal lymphatics, to deep cervical lymph nodes [115].

(4) Studies on mouse models have indicated that local production of $\mathrm{A} \beta$ by vascular elements is not absolutely essential for the development of CAA. This is important as, for instance, hypoxia followed by reoxygenation in microvascular smooth vessel cells has been shown to upregulate APP and proposed to be an initiating event in the pathogenesis of amyloid angiopathy [116]. However, mice that solely produce APP/A $\beta$ from neuronal cells in an endogenous APP knockout background drive $A \beta$ pathology in both parenchyma and vessels [114]. Furthermore, these studies also lend support to the hypothesis that failure of $A \beta$ vascular drainage and entrapment of $A \beta$ in the periarterial space leads to development of CAA [56]. Similarly, pathological studies on some of the mouse models have suggested that in certain situations, dense plaques in mouse models are also associated with vascular walls as has been proposed earlier for sporadic AD [117] and shown for Flemish APP pathology [33]. Recent data from $\operatorname{Tg} 2576$ and PSAPP mice show that up to $90 \%$ of these dense plaques, but not diffuse plaques, are centred on vessel walls or reside in the immediate perivascular regions [99]. Similar observations have also been made on Tg-SwDI mice where all dense plaques were observed to be associated with vessel walls [93]. These data suggest that the mechanisms involved in the formation of "neuritic" dense (core) plaques in select AD such as Flemish APP pathology or in select transgenic mice such as Tg2576 and PSAPP mice are similar to CAA formation, but distinct from those involved in the formation of non-neuritic, diffuse plaques (Figure 3). 
Figure 3. Physiological clearance and pathological deposition of $A \beta$ in brain.

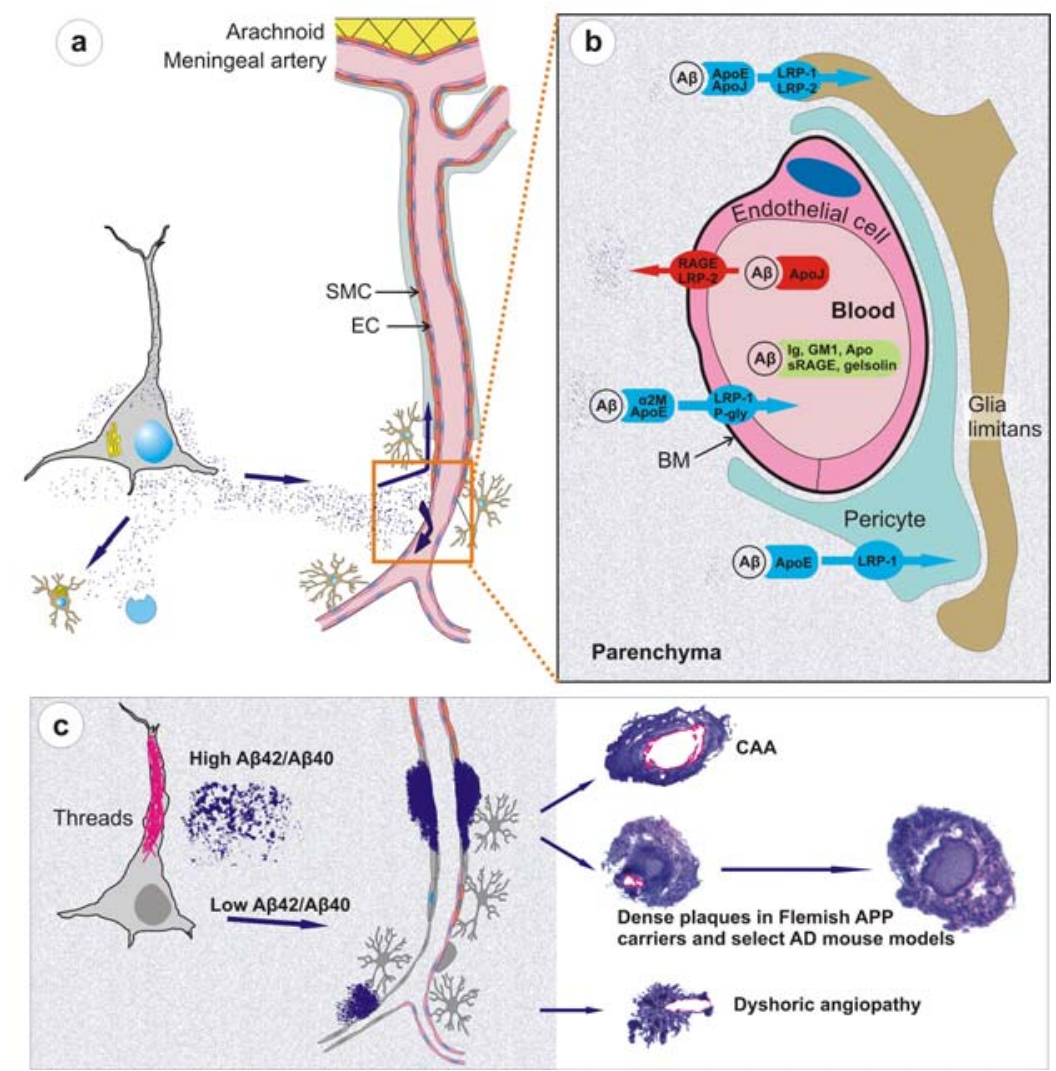

(a) The newly synthesized $\mathrm{A} \beta$ is locally degraded by glial uptake and cell-associated and extracellular proteases or cleared along the periarterial interstitial fluid pathway or directly across the BBB through specific receptors or carrier-mediated mechanisms (EC, endothelial cell; SMC, smooth muscle cell). (b) At the level of $\mathrm{BBB}, \mathrm{A} \beta$ is transported into the blood flow via a transcytosis mechanism mediated by LRP-1 and P glycoprotein transporters, in association with $\alpha 2$ macroglobulin and ApoE. A reverse transport from the blood towards the parenchyma is mediated by RAGE and LRP-2 receptors in association with apolipoprotein $J$. In addition, A $\beta$ might be sequestered in the blood flow by immunoglobulins, ganglioside GM1, apolipoproteins, soluble RAGE receptors and gelsolin. (c) Astrocyte endfeet and pericytes also mediate $A \beta$ intake by expressing LRP-1 and -2 receptors. As the production of $A \beta$ exceeds its clearance, $A \beta$ starts to deposit. It is possible that in situations of high $A \beta 42 / A \beta 40$ ratio, highly fibrillogenic $A \beta 42$ deposits near the site of production as diffuse plaques. It is also likely that such plaques sequester newly synthesized $A \beta$ and mature to dense plaques. However, in situations where $A \beta 42 / A \beta 40$ ratio remains unaltered or low, the major $A \beta$ gradient is set towards vessels where $A \beta 42$ seeds the deposition of more abundantly produced, and more diffusible, A 340 to form vessel-related CAA and dense plaques. Figure is not drawn to scale (adapted from Pirici et al., with permission from the publisher [118].

(5) Mouse models demonstrate that similar to large vessel-CAA in humans [119], amyloid associated with vessel walls is predominantly of the A $\beta 40$ type. A similar biochemical profile is also observed for the compact dense-core plaques, which is in contrast to diffuse plaques that are predominantly composed of $A \beta 42$ [120]. Conversely, situations that lead to a drastic 
reduction of $\mathrm{A} \beta 40$ also drastically reduce the prevalence of CAA and dense-core plaques as observed in Austrian APP pathology [102]. Tg2576 and PSAPP mouse models preferentially producing $A \beta 40$ also deposit A $\beta 40$-enriched cerebrovascular amyloid [121,99]. Dutch APP mice also deposit more mutant $A \beta 40$ than mutant $A \beta 42$ in vessels [91]. Furthermore, experimental work on rodents has demonstrated that $A \beta 40$ is more prone to compact as dense deposits in contrast to the faster aggregating $A \beta 42$ that preferentially deposits as diffuse plaques. When soluble $\mathrm{A} \beta 40$ and $\mathrm{A} \beta 42$ are injected in rat brain, soluble $\mathrm{A} \beta 40$ forms congophilic, fibrillar dense deposits while $A \beta 1-42$ forms only diffuse deposits [122]. Lastly, BRI-A $\beta 42$ mice that solely secrete $A \beta 42$ also have $A \beta 42$ peptide trafficked and deposited in vessels [100]. Thus, mouse models support the viewpoint that although "A $\beta 40$ " plays an important role in development of vessel-associated compact plaques, most likely due to a more efficient vascular clearance and its high abundance, $A \beta 42$ on its own also has the potential to migrate and deposit in association with vessels; and without a critical relative level of $A \beta 42$, A $\beta 40$ clearance is too efficient to allow deposition.

(6) Mouse models have partly elucidated the role of ApoE which is otherwise poorly understood. ApoE has been shown to bind to $A \beta[123]$, and studies on transgenic mice suggest that ApoE, especially ApoE- $\varepsilon 4$, has a role in A $\beta$ fibrillization [124]. When APP London mice are crossbred with ApoE knockout mice, $A \beta$ chiefly deposits as diffuse, nonfibrillar plaques. However, when these mice were crossbred with mice transgenically expressing human ApoE- $\varepsilon 4$, they develop far more fibrillogenic, dense-core plaques and CAA than when crossbred with mice expressing the ApoE- $\varepsilon 3$ isoform [124]. Because dense-core plaques and CAA are rich in A $\beta 40$, these data suggest that ApoE- $\varepsilon 4$ has a role in A $\beta 40$ fibrillization as also suggested by studies on AD [125].

(7) Transgenic mouse models serve as a useful model to study CAA-associated pathological changes. Vascular $A \beta$ deposits in mouse models are shown to cause degeneration of vascular smooth muscle cells and of other vascular components typically identified in AD and hereditary cerebral amyloidosis [126,91,11]. Some mouse models also show ultrastructural microvascular abnormalities in non-amyloidotic vessels such as endothelial cell loss, basement membrane thickening, and degeneration of smooth muscle cells and pericytes as shown for AD [99,11]. Additionally, mouse models have shown that basement membrane abnormalities could also contribute to development of CAA as capillary basement membrane thickening precedes the development of CAA in TGF- $\beta$ transgenic mice [127]. And lastly, transgenic mouse models such as APP23 and Tg2576 have shown that vascular amyloidosis is indeed the cause of spontaneous haemorrhages as both cerebral microhaemorrhages and fatal lobar haemorrhages occur in these mice $[126,99]$.

(8) Finally, mouse models of amyloidosis have proved to be essential in testing therapeutic amyloid targeting from vessels. A number of active and passive immunotherapeutic approaches such as peripheral sequestering utilizing non-immune mechanisms have been successfully tried in these mouse models [128,129,130,131,132]. In an active immunization trial on an AD mouse model, behavioural and cognitive abnormalities were shown to be reversed coinciding with $\approx 50 \%$ reduction in dense-core plaques [129]. Similarly, a passive immunization approach in Tg2576 mouse model has been shown to revert some of the BBB abnormalities observed in these mice [133]. Furthermore, mouse models also reproduce some of the side effects of anti-A $\beta$ 
vaccinations. For instance, similar to one of the encephalitic patients from the A $\beta$ active immunization trial revealing presence of multiple cortical haemorrhages in association with $\mathrm{T}$ cell inflammatory infiltrates [134], APP23 mice receiving passive anti-A $\beta$ immunization were also shown to have infrequent but severe CAA-associated microhaemorrhages [135]. Furthermore, similar to breakdown of BBB seen in $\operatorname{Tg} 2576$ [99], autopsy of one of the encephalitic patients from the active immunization trial revealed that antibody titers in cerebrospinal fluid equalled those in plasma, again indicating a severe breakdown of the BBB [136]. These data indicate that mouse models of amyloidosis could be instrumental in understanding some of the ill effects of anti-amyloid drug targeting. However, data from mouse models should always be viewed with caution as mouse models also have serious limitations as reviewed recently [72]. As an example, vaccination trials targeting $A \beta N$-terminus in humanized mouse models could easily miss the adverse effects caused by sequestration of physiological A $\beta$ because human and murine $\mathrm{A} \beta$ have a different $\mathrm{N}$-terminus. Despite these limitations, mouse models would continue to provide important clues in the understanding of the processes involved in vascular amyloidosis and in causing dementia.

\section{Conclusions}

In this review, I have discussed how molecular pathology of hereditary cerebrovascular amyloidosis due to APP mutations within the A $\beta$ domain, as well as experimental studies in transgenic mouse models have helped to partially dissect molecular mechanisms involved in $\mathrm{A} \beta$ cerebrovascular amyloidosis. Firstly, the mutant forms of $\mathrm{A} \beta$ causing $\mathrm{AD} /$ cerebral haemorrhage were discussed that strongly support the role of APP in the disease mechanism and provide one of the strongest rationales for studies of factors that influence abnormal metabolism and aggregation of $A \beta$ in the causation of CAA with or without AD. Secondly, studies on hereditary cerebrovascular amyloidosis and mouse models were discussed that suggest that while an absolute or relative increase in $A \beta 42$ or an increased $\mathrm{A} \beta 42 / \mathrm{A} \beta 40$ ratio is important for parenchymal plaque deposition and development of an $\mathrm{AD}$ phenotype, increased $A \beta$ with an unaltered $A \beta 42 / A \beta 40$ ratio favours cerebrovascular amyloidosis. However, critical relative levels of $A \beta 42$ are also important as without this, the clearance of $A \beta$ is too efficient to allow deposition. Thirdly, these data suggest that a low fibrillogenic potential of $A \beta$ could also favour plaque compaction as is the case with Flemish $\mathrm{A} \beta$ that leads to the formation of large, neuritic, dense-core plaques. And lastly, by illuminating the relationships between specific lesions such as CAA and dense-core plaques and their molecular components, studies on hereditary cerebrovascular amyloidosis and mouse models have shown that CAA and dense-core plaques could be a spectrum of the same disease mechanism. Thus, molecular pathological studies of cerebrovascular amyloidosis and relevant mouse models would continue to provide detailed insights into the pathogenesis of CAA and contribute to the development of targeted therapeutic strategies.

\section{Acknowledgements}

Our research group is supported by the Special Research Fund of the University of Antwerp, the Fund for Scientific Research-Flanders (FWO-V), the Institute for the Promotion of Innovation through Science and Technology in Flanders (IWT-V), the Interuniversity Attraction Poles (IAP) program 
P6/43 of the Belgian Science Policy Office (BELSPO), and the Foundation for Alzheimer Research (SAO/FRMA); Belgium. The author thanks the BioBank of the Institute Born-Bunge for the brain samples of $\mathrm{AD}$ patients.

\section{References}

1. Vinters, H.V.; Wang, Z.Z.; Secor, D.L. Brain parenchymal and microvascular amyloid in Alzheimer's disease. Brain Pathol. 1996, 6, 179-195.

2. Jellinger, K.A. Alzheimer disease and cerebrovascular pathology: an update. J. Neural Transm. 2002, 109, 813-836.

3. Revesz, T.; Holton, J.L.; Lashley, T.; Plant, G.; Frangione, B.; Rostagno, A.; Ghiso, J. Genetics and molecular pathogenesis of sporadic and hereditary cerebral amyloid angiopathies. Acta Neuropathol. 2009. [Epub ahead of print]

4. Hardy, J.; Selkoe, D.J. The amyloid hypothesis of Alzheimer's disease: progress and problems on the road to therapeutics. Science 2002, 297, 353-356.

5. Scholtz, W. Studien zur Pathologie der Hirngefässe. II. Die drüsige Entartung der Hirnarterien und -capillären. Z.Gesamte.Neurol.Psychiat. 1938, 162, 694-715.

6. Mandybur, T.I. The incidence of cerebral amyloid angiopathy in Alzheimer's disease. Neurology 1975, 25, 120-126.

7. Thal, D.R.; Ghebremedhin, E.; Rub, U.; Yamaguchi, H.; Del Tredici, K.; Braak, H. Two types of sporadic cerebral amyloid angiopathy. J. Neuropathol. Exp. Neurol. 2002, 61, 282-293.

8. Surbeck, E. L'angiopathie dyshorique (Morel) d l'ecorce cerebrale Etude anatomoclinique et statistique: Aspect genetique. Thesis. University of Geneva: Geneva, Switzerland, 1961.

9. Vonsattel, J.P.; Myers, R.H.; Hedley-Whyte, E.T.; Ropper, A.H.; Bird, E.D.; Richardson, E.P., Jr. Cerebral amyloid angiopathy without and with cerebral hemorrhages: a comparative histological study. Ann. Neurol. 1991, 30, 637-649.

10. Kalaria, R.N.; Ballard, C. Overlap between pathology of Alzheimer disease and vascular dementia. Alzheimer. Dis. Assoc. Disord. 1999, 13 (Suppl 3), S115-23, S115-S123.

11. Farkas, E.; Luiten, P.G.M. Cerebral microvascular pathology in aging and Alzheimer's disease. Prog. Neurobiol. 2001, 64, 575-611.

12. Okazaki, H.; Reagan, T.J.; Campbell, R.J. Clinicopathologic studies of primary cerebral amyloid angiopathy. Mayo Clin.Proc. 1979, 54, 22-31.

13. Mandybur, T.I. Cerebral amyloid angiopathy: the vascular pathology and complications. $J$. Neuropathol. Exp. Neurol. 1986, 45, 79-90.

14. Vinters, H.V. Cerebral amyloid angiopathy. A critical review. Stroke 1987, 18, 311-324.

15. O'Donnell, H.C.; Rosand, J.; Knudsen, K.A.; Furie, K.L.; Segal, A.Z.; Chiu, R.I.; Ikeda, D.; Greenberg, S.M. Apolipoprotein E genotype and the risk of recurrent lobar intracerebral hemorrhage. N. Engl. J. Med. 2000, 342, 240-245.

16. Jellinger, K.A.; Lauda, F.; Attems, J. Sporadic cerebral amyloid angiopathy is not a frequent cause of spontaneous brain hemorrhage. Eur. J. Neurol. 2007, 14, 923-928. 
17. Snowdon, D.A.; Greiner, L.H.; Mortimer, J.A.; Riley, K.P.; Greiner, P.A.; Markesbery, W.R. Brain infarction and the clinical expression of Alzheimer disease. The Nun Study [see comments]. JAMA 1997, 277, 813-817.

18. Cadavid, D.; Mena, H.; Koeller, K.; Frommelt, R.A. Cerebral beta amyloid angiopathy is a risk factor for cerebral ischemic infarction. A case control study in human brain biopsies. $J$. Neuropathol. Exp. Neurol. 2000, 59, 768-773.

19. Suter, O.C.; Sunthorn, T.; Kraftsik, R.; Straubel, J.; Darekar, P.; Khalili, K.; Miklossy, J. Cerebral hypoperfusion generates cortical watershed microinfarcts in Alzheimer disease. Stroke 2002, 33, 1986-1992.

20. Gray, F.; Dubas, F.; Roullet, E.; Escourolle, R. Leukoencephalopathy in diffuse hemorrhagic cerebral amyloid angiopathy. Ann. Neurol. 1985, 18, 54-59.

21. Greenberg, S.M.; Vonsattel, J.P.; Stakes, J.W.; Gruber, M.; Finklestein, S.P. The clinical spectrum of cerebral amyloid angiopathy: presentations without lobar hemorrhage. Neurology 1993, 43, 2073-2079.

22. Attems, J.; Quass, M.; Jellinger, K.A.; Lintner, F. Topographical distribution of cerebral amyloid angiopathy and its effect on cognitive decline are influenced by Alzheimer disease pathology. $J$. Neurol. Sci. 2007, 257, 49-55.

23. Vidal, R.; Calero, M.; Piccardo, P.; Farlow, M.R.; Unverzagt, F.W.; Mendez, E.; Jimenez-Huete, A.; Beavis, R.; Gallo, G.; Gomez-Tortosa, E.; Ghiso, J.; Hyman, B.T.; Frangione, B.; Ghetti, B. Senile dementia associated with amyloid beta protein angiopathy and tau perivascular pathology but not neuritic plaques in patients homozygous for the APOE-epsilon4 allele. Acta Neuropathol.(Berl) 2000, 100, 1-12.

24. Attems, J.; Jellinger, K.A. Only cerebral capillary amyloid angiopathy correlates with Alzheimer pathology—a pilot study. Acta Neuropathol.(Berl) 2004, 107, 83-90.

25. Glenner, G.G.; Wong, C.W. Alzheimer's disease: Initial report of the purification and characterization of a novel cerebrovascular amyloid protein. Biochem. Biophys. Res. Commun. 1984, 122, 885-890.

26. van Duinen, S.G.; Castaño, E.M.; Prelli, F.; Bots, G.T.A.B.; Luyendijk, W.; Frangione, B. Hereditary cerebral hemorrhage with amyloidosis in patients of Dutch origin is related to Alzheimer disease. Proc. Natl. Acad. Sci. USA 1987, 84, 5991-5994.

27. Haan, J.; Hardy, J.A.; Roos, R.A.C. Hereditary cerebral hemorrhage with amyloidosis-Dutch type: its importance for Alzheimer research. TINS 1991, 14, 231-234.

28. Maat-Schieman, M.L.; Yamaguchi, H.; van Duinen, S.G.; Natte, R.; Roos, R.A. Age-related plaque morphology and C-terminal heterogeneity of amyloid beta in Dutch-type hereditary cerebral hemorrhage with amyloidosis. Acta Neuropathol.(Berl) 2000, 99, 409-419.

29. Levy, E.; Carman, M.D.; Fernandez-Madrid, I.J.; Power, M.D.; Lieberburg, I.; van Duinen, S.G.; Bots, G.T.; Luyendijk, W.; Frangione, B. Mutation of the Alzheimer's disease amyloid gene in hereditary cerebral hemorrhage, Dutch type. Science 1990, 248, 1124-1126.

30. Van Broeckhoven, C.; Haan, J.; Bakker, E.; Hardy, J.A.; Van Hul, W.; Wehnert, A.; Vegter-Van, d.V.; Roos, R.A. Amyloid beta protein precursor gene and hereditary cerebral hemorrhage with amyloidosis (Dutch). Science 1990, 248, 1120-1122. 
31. Hendriks, L.; van Duijn, C.M.; Cras, P.; Cruts, M.; Van Hul, W.; van Harskamp, F.; Warren, A.; McInnis, M.G.; Antonarakis, S.E.; Martin, J.-J.; Hofman, A.; Van Broeckhoven, C. Presenile dementia and cerebral haemorrhage linked to a mutation at condon 692 of the $\beta$-amyloid precursor protein gene. Nat. Genet. 1992, 1, 218-221.

32. Roks, G.; van Harskamp, F.; De, K., I; Cruts, M.; De Jonghe, C.; Kumar-Singh, S.; Tibben, A.; Tanghe, H.; Niermeijer, M.F.; Hofman, A.; van Swieten, J.C.; Van Broeckhoven, C.; van Duijn, C.M. Presentation of amyloidosis in carriers of the codon 692 mutation in the amyloid precursor protein gene (APP692). Brain 2000, 123, 2130-2140.

33. Kumar-Singh, S.; Cras, P.; Wang, R.; Kros, J.M.; van Swieten, J.; Lubke, U.; Ceuterick, C.; Serneels, S.; Vennekens, K.; Timmermans, J.-P.; Van Marck, E.; Martin, J.-J.; van Duijn, C.; Van Broeckhoven, C. Dense-core senile plaques in the Flemish variant of Alzheimer's disease are vasocentric. Am J Pathol 2002, 161, 507-520.

34. Cras, P.; van Harskamp, F.; Hendriks, L.; Ceuterick, C.; van Duijn, C.M.; Stefanko, S.Z.; Hofman, A.; Kros, J.M.; Van Broeckhoven, C.; Martin, J.J. Presenile Alzheimer dementia characterized by amyloid angiopathy and large amyloid core type senile plaques in the APP 692Ala-->Gly mutation. Acta Neuropathol. 1998, 96, 253-260.

35. Brooks, W.S.; Kwok, J.B.; Halliday, G.M.; Godbolt, A.K.; Rossor, M.N.; Creasey, H.; Jones, A.O.; Schofield, P.R. Hemorrhage is uncommon in new Alzheimer family with Flemish amyloid precursor protein mutation. Neurology 2004, 63, 1613-1617.

36. Miravalle, L.; Tokuda, T.; Chiarle, R.; Giaccone, G.; Bugiani, O.; Tagliavini, F.; Frangione, B.; Ghiso, J. Substitutions at codon 22 of Alzheimer's A beta\} peptide induce conformational changes and diverse apoptotic effects in human cerebral endothelial cells. J. Biol. Chem. 2000, 275, 27110-27116.

37. Obici, L.; Demarchi, A.; de Rosa, G.; Bellotti, V.; Marciano, S.; Donadei, S.; Arbustini, E.; Palladini, G.; Diegoli, M.; Genovese, E.; Ferrari, G.; Coverlizza, S.; Merlini, G. A novel AbetaPP mutation exclusively associated with cerebral amyloid angiopathy. Ann. Neurol. 2005, 58, 639-644.

38. Nilsberth, C.; Westlind-Danielsson, A.; Eckman, C.; Condron, M.M.; Axelman, K.; Forsell, C.; Stenh, C.; Luthman, H.; Teplow, D.B.; Younkin, S.G.; Naslund, J.; Lannfelt, L. The 'Arctic' APP mutation $(\mathrm{E} 693 \mathrm{G})$ causes Alzheimer's disease by enhanced Abeta protofibril formation. Nat. Neurosci. 2001, 4, 887-893.

39. Basun, H.; Bogdanovic, N.; Ingelsson, M.; Almkvist, O.; Naslund, J.; Axelman, K.; Bird, T.D.; Nochlin, D.; Schellenberg, G.D.; Wahlund, L.O.; Lannfelt, L. Clinical and neuropathological features of the arctic APP gene mutation causing early-onset Alzheimer disease. Arch. Neurol. 2008, 65, 499-505.

40. Grabowski, T.J.; Cho, H.S.; Vonsattel, J.P.; Rebeck, G.W.; Greenberg, S.M. Novel Amyloid Precursor Protein Mutation in an Iowa Family with Dementia and Severe Cerebral Amyloid Angiopathy. Ann. Neurol. 2001, 49, 697-705.

41. Greenberg, S.M.; Shin, Y.; Grabowski, T.J.; Cooper, G.E.; Rebeck, G.W.; Iglesias, S.; Chapon, F.; Tournier-Lasserve, E.; Baron, J.C. Hemorrhagic stroke associated with the Iowa amyloid precursor protein mutation. Neurology 2003, 60, 1020-1022. 
42. Rossi, G.; Giaccone, G.; Maletta, R.; Morbin, M.; Capobianco, R.; Mangieri, M.; Giovagnoli, A.R.; Bizzi, A.; Tomaino, C.; Perri, M.; Di, N.M.; Tagliavini, F.; Bugiani, O.; Bruni, A.C. A family with Alzheimer disease and strokes associated with A713T mutation of the APP gene. Neurology 2004, 63, 910-912.

43. Di Fede, G.; Catania, M.; Morbin, M.; Rossi, G.; Suardi, S.; Mazzoleni, G.; Merlin, M.; Giovagnoli, A.R.; Prioni, S.; Erbetta, A.; Falcone, C.; Gobbi, M.; Colombo, L.; Bastone, A.; Beeg, M.; Manzoni, C.; Francescucci, B.; Spagnoli, A.; Cantu, L.; Del, F.E.; Levy, E.; Salmona, M.; Tagliavini, F. A recessive mutation in the APP gene with dominant-negative effect on amyloidogenesis. Science 2009, 323, 1473-1477.

44. Van Broeckhoven, C.; Haan, J.; Bakker, E.; Hardy, J.A.; Van Hul, W.; Wehnert, A.; Vegter-Van, d.V.; Roos, R.A. Amyloid beta protein precursor gene and hereditary cerebral hemorrhage with amyloidosis (Dutch). Science 1990, 248, 1120-1122.

45. Tomiyama, T.; Nagata, T.; Shimada, H.; Teraoka, R.; Fukushima, A.; Kanemitsu, H.; Takuma, H.; Kuwano, R.; Imagawa, M.; Ataka, S.; Wada, Y.; Yoshioka, E.; Nishizaki, T.; Watanabe, Y.; Mori, H. A new amyloid beta variant favoring oligomerization in Alzheimer's-type dementia. Ann. Neurol. 2008, 63, 377-387.

46. Kumar-Singh, S.; De Jonghe, C.; Cruts, M.; Kleinert, R.; Wang, R.; Mercken, M.; De Strooper, B.; Vanderstichele, H.; Lofgren, A.; Vanderhoeven, I.; Backhovens, H.; Vanmechelen, E.; Kroisel, P.M.; Van Broeckhoven, C. Nonfibrillar diffuse amyloid deposition due to a gamma(42)-secretase site mutation points to an essential role for N-truncated abeta(42) in Alzheimer's disease. Hum. Mol. Genet. 2000, 9, 2589-2598.

47. Jarrett, J.T.; Berger, E.P.; Lansbury, P.T.Jr. The carboxy terminus of the -amyloid protein is critical for the seeding of amyloid formation: Implications for the pathogenesis of Alzheimer's disease. Biochemistry 1993, 32, 4693-4697.

48. Wisniewski, T.; Ghiso, J.; Frangione, B. Peptides homologous to the amyloid protein of Alzheimer's disease containing a glutamine for glutamic acid substitution have accelerated amyloid fibril formation. Biochem. Biophys. Res. Commun. 1991, 179, 1247-1254.

49. Fraser, P.E.; Nguyen, J.T.; Inouye, H.; Surewicz, W.K.; Selkoe, D.J.; Podlisny, M.B.; Kirschner, D.A. Fibril formation by primate, rodent and Dutch-hemorrhagic analogues of Alzheimer amyloid $\beta$-protein. Biochemistry. 1992, 31, 10716-10723.

50. Walsh, D.M.; Hartley, D.M.; Condron, M.M.; Selkoe, D.J.; Teplow, D.B. In vitro studies of amyloid beta-protein fibril assembly and toxicity provide clues to the aetiology of Flemish variant (Ala692-->Gly) Alzheimer's disease. Biochem. J. 2001, 355, 869-877.

51. Kumar-Singh, S.; Julliams, A.; Nuyens, D.; Labeur, C.; Vennekens, K.; Serneels, S.; Van Osta, P.; Geerts, H.; De Strooper, B.; Van Broeckhoven, C. In vitro studies of Flemish, Dutch, and wild type Amyloid $\beta(A \beta)$ provide evidence for a two-stage $A ß$ neurotoxicity. Neurobiol Dis. 2002, 11, 300-310.

52. Walsh, D.M.; Klyubin, I.; Fadeeva, J.V.; Cullen, W.K.; Anwyl, R.; Wolfe, M.S.; Rowan, M.J.; Selkoe, D.J. Naturally secreted oligomers of amyloid beta protein potently inhibit hippocampal long-term potentiation in vivo. Nature 2002, 416, 535-539. 
53. Davis-Salinas, J.; Van Nostrand, W.E. Amyloid beta-protein aggregation nullifies its pathologic properties in cultured cerebrovascular smooth muscle cells. J. Biol. Chem. 1995, 270, 20887-20890.

54. Maat-Schieman, M.L.; van Duinen, S.G.; Bornebroek, M.; Haan, J.; Roos, R.A. Hereditary cerebral hemorrhage with amyloidosis-Dutch type (HCHWA-D): II-A review of histopathological aspects. Brain Pathol. 1996, 6, 115-120.

55. Farzan, M.; Schnitzler, C.E.; Vasilieva, N.; Leung, D.; Choe, H. BACE2, a beta -secretase homolog, cleaves at the beta site and within the amyloid-beta region of the amyloid-beta precursor protein. Proc. Natl. Acad. Sci. U.S.A 2000, 97, 9712-9717.

56. Weller, R.O.; Massey, A.; Newman, T.A.; Hutchings, M.; Kuo, Y.M.; Roher, A.E. Cerebral amyloid angiopathy: amyloid beta accumulates in putative interstitial fluid drainage pathways in Alzheimer's disease. Am. J. Pathol. 1998, 153, 725-733.

57. Zlokovic, B.V. Neurovascular mechanisms of Alzheimer's neurodegeneration. Trends Neurosci. 2005, 28, 202-208.

58. Cullen, K.M.; Kocsi, Z.; Stone, J. Microvascular pathology in the aging human brain: Evidence that senile plaques are sites of microhaemorrhages . Neurobiol Aging 2006, 27, 1786-1796.

59. Melchor, J.P.; McVoy, L.; Van Nostrand, W.E. Charge alterations of E22 enhance the pathogenic properties of the amyloid beta-protein. J.Neurochem. 2000, 74, 2209-2212.

60. Murakami, K.; Irie, K.; Morimoto, A.; Ohigashi, H.; Shindo, M.; Nagao, M.; Shimizu, T.; Shirasawa, T. Synthesis, aggregation, neurotoxicity, and secondary structure of various A beta 142 mutants of familial Alzheimer's disease at positions 21-23. Biochem. Biophys. Res. Commun. 2002, 294, 5-10.

61. Tsubuki, S.; Takaki, Y.; Saido, T.C. Dutch, Flemish, Italian, and Arctic mutations of APP and resistance of Abeta to physiologically relevant proteolytic degradation. Lancet 2003, 361, 1957-1958.

62. Betts, V.; Leissring, M.A.; Dolios, G.; Wang, R.; Selkoe, D.J.; Walsh, D.M. Aggregation and catabolism of disease-associated intra-Abeta mutations: reduced proteolysis of AbetaA21G by neprilysin. Neurobiol. Dis. 2008, 31, 442-450.

63. Yamamoto, N.; Van Nostrand, W.E.; Yanagisawa, K. Further evidence of local gangliosidedependent amyloid beta-protein assembly in brain. Neuroreport 2006, 17, 1735-1737.

64. Deane, R.; Wu, Z.H.; Sagare, A.; Davis, J.; Yan, S.D.; Hamm, K.; Xu, F.; Parisi, M.; Larue, B.; Hu, H.W.; Spijkers, P.; Guo, H.; Song, X.M.; Lenting, P.J.; Van Nostrand, W.E.; Zlokovic, B.V. LRP/amyloid beta-peptide interaction mediates differential brain efflux of $\mathrm{A}$ beta isoforms. Neuron 2004, 43, 333-344.

65. Davis, J.; Xu, F.; Miao, J.; Previti, M.L.; Romanov, G.; Ziegler, K.; Van Nostrand, W.E. Deficient cerebral clearance of vasculotropic mutant Dutch/Iowa Double A beta in human A betaPP transgenic mice. Neurobiol. Aging 2006, 27, 946-954.

66. Lemere, C.A.; Blusztajn, J.K.; Yamaguchi, H.; Wisniewski, T.; Saido, T.C.; Selkoe, D.J. Sequence of deposition of heterogeneous amyloid beta-peptides and APOE in Down syndrome: implications for initial events in amyloid plaque formation. Neurobiol. Dis. 1996, 3, 16-32.

67. Belza, M.G.; Urich, H. Cerebral amyloid angiopathy in Down's syndrome. Clin.Neuropathol. 1986, 5, 257-260. 
68. Donahue, J.E.; Khurana, J.S.; Adelman, L.S. Intracerebral hemorrhage in two patients with Down's syndrome and cerebral amyloid angiopathy. Acta Neuropathol.(Berl) 1998, 95, 213-216.

69. McCarron, M.O.; Nicoll, J.A.; Graham, D.I. A quartet of Down's syndrome, Alzheimer's disease, cerebral amyloid angiopathy, and cerebral haemorrhage: interacting genetic risk factors. $J$. Neurol. Neurosurg. Psychiatry 1998, 65, 405-406.

70. Rovelet-Lecrux, A.; Hannequin, D.; Raux, G.; Meur, N.L.; Laquerriere, A.; Vital, A.; Dumanchin, C.; Feuillette, S.; Brice, A.; Vercelletto, M.; Dubas, F.; Frebourg, T.; Campion, D. APP locus duplication causes autosomal dominant early-onset Alzheimer disease with cerebral amyloid angiopathy. Nat. Genet. 2006, 38, 24-26.

71. Sleegers, K.; Brouwers, N.; Gijselinck, I.; Theuns, J.; Goossens, D.; Wauters, J.; Del Favero, J.; Cruts, M.; van Duijn, C.M.; Van Broeckhoven, C. APP duplication is sufficient to cause early onset Alzheimer's dementia with cerebral amyloid angiopathy. Brain 2006, 129 (Pt 11), 2977-2983.

72. Kumar-Singh, S. Cerebral amyloid angiopathy: pathogenetic mechanisms and link to dense amyloid plaques. Genes Brain Behav. 2008, 7, 67-82.

73. Ikeda, M.; Sharma, V.; Sumi, S.M.; Rogaeva, E.A.; Poorkaj, P.; Sherrington, R.; Nee, L.; Tsuda, T.; Oda, N.; Watanabe, M.; Aoki, M.; Shoji, M.; Abe, K.; Itoyama, Y.; Hirai, S.; Schellenberg, G.D.; Bird, T.D.; George-Hyslop, P.H. The clinical phenotype of two missense mutations in the presenilin I gene in Japanese patients. Ann. Neurol. 1996, 40, 912-917.

74. Yasuda, M.; Maeda, K.; Ikejiri, Y.; Kawamata, T.; Kuroda, S.; Tanaka, C. A novel missense mutation in the presenilin-1 gene in a familial Alzheimer's disease pedigree with abundant amyloid angiopathy. Neurosci. Lett. 1997, 232, 29-32.

75. Wegiel, J.; Wisniewski, H.M.; Kuchna, I.; Tarnawski, M.; Badmajew, E.; Popovitch, E.; Kulczycki, J.; Dowjat, W.K.; Wisniewski, T. Cell-type-specific enhancement of amyloid-beta deposition in a novel presenilin-1 mutation (P117L). J. Neuropathol. Exp. Neurol. 1998, 57, 831-838.

76. Singleton, A.B.; Hall, R.; Ballard, C.G.; Perry, R.H.; Xuereb, J.H.; Rubinsztein, D.C.; Tysoe, C.; Matthews, P.; Cordell, B.; Kumar-Singh, S.; De Jonghe, C.; Cruts, M.; Van Broeckhoven, C.; Morris, C.M. Pathology of early-onset Alzheimer's disease cases bearing the Thr113- 114ins presenilin-1 mutation. Brain 2000, 123 Pt 12, 2467-2474.

77. Dermaut, B.; Kumar-Singh, S.; De Jonghe, C.; Cruts, M.; Lofgren, A.; Lubke, U.; Cras, P.; Dom, R.; De Deyn, P.P.; Martin, J.J.; Van Broeckhoven, C. Cerebral amyloid angiopathy is a pathogenic lesion in Alzheimer's disease due to a novel presenilin 1 mutation. Brain 2001, 124, 2383-2392.

78. Nochlin, D.; Bird, T.D.; Nemens, E.J.; Ball, M.J.; Sumi, S.M. Amyloid angiopathy in a Volga German family with Alzheimer's disease and a presenilin-2 mutation (N141I). Ann. Neurol. 1998, 43, 131-135.

79. Mann, D.M.; Pickering-Brown, S.M.; Takeuchi, A.; Iwatsubo, T. Amyloid Angiopathy and Variability in Amyloid beta Deposition Is Determined by Mutation Position in Presenilin-1Linked Alzheimer's Disease. Am. J. Pathol. 2001, 158, 2165-2175.

80. Kumar-Singh, S.; Theuns, J.; Van Broeck, B.; Pirici, D.; Vennekens, K.; Corsmit, E.; Cruts, M.; Dermaut, B.; Wang, R.; Van Broeckhoven, C. Mean age-of-onset of familial alzheimer disease 
caused by presenilin mutations correlates with both increased Abeta42 and decreased Abeta40. Hum. Mutat. 2006, 27, 686-695.

81. Bentahir, M.; Nyabi, O.; Verhamme, J.; Tolia, A.; Horre, K.; Wiltfang, J.; Esselmann, H.; De Strooper, B. Presenilin clinical mutations can affect gamma-secretase activity by different mechanisms. J. Neurochem. 2006, 96, 732-742.

82. Greenberg, S.M.; Rebeck, G.W.; Vonsattel, J.P.; Gomez-Isla, T.; Hyman, B.T. Apolipoprotein E epsilon 4 and cerebral hemorrhage associated with amyloid angiopathy. Ann. Neurol. 1995, 38, 254-259.

83. Premkumar, D.R.; Cohen, D.L.; Hedera, P.; Friedland, R.P.; Kalaria, R.N. Apolipoprotein Eepsilon4 alleles in cerebral amyloid angiopathy and cerebrovascular pathology associated with Alzheimer's disease. Am. J. Pathol. 1996, 148, 2083-2095.

84. Attems, J.; Lauda, F.; Jellinger, K.A. Unexpectedly low prevalence of intracerebral hemorrhages in sporadic cerebral amyloid angiopathy: an autopsy study. J. Neurol. 2008, 255, 70-76.

85. Nicoll, J.A.; Burnett, C.; Love, S.; Graham, D.I.; Dewar, D.; Ironside, J.W.; Stewart, J.; Vinters, H.V. High frequency of apolipoprotein E epsilon 2 allele in hemorrhage due to cerebral amyloid angiopathy. Ann. Neurol. 1997, 41, 716-721.

86. McCarron, M.O.; Nicoll, J.A.; Stewart, J.; Ironside, J.W.; Mann, D.M.; Love, S.; Graham, D.I.; Dewar, D. The apolipoprotein E epsilon2 allele and the pathological features in cerebral amyloid angiopathy-related hemorrhage. J. Neuropathol. Exp. Neurol. 1999, 58, 711-718.

87. Bertram, L.; Tanzi, R.E. Thirty years of Alzheimer's disease genetics: the implications of systematic meta-analyses. Nat. Rev. Neurosci. 2008, 9, 768-778.

88. Yamada, M.; Sodeyama, N.; Itoh, Y.; Takahashi, A.; Otomo, E.; Matsushita, M.; Mizusawa, H. Association of neprilysin polymorphism with cerebral amyloid angiopathy. J. Neurol. Neurosurg. Psychiatry 2003, 74, 749-751.

89. Howland, D.S.; Savage, M.J.; Huntress, F.A.; Wallace, R.E.; Schwartz, D.A.; Loh, T.; Melloni, R.H.J.; DeGennaro, L.J.; Greenberg, B.D.; Siman, R. Mutant and native human beta-amyloid precursor proteins in transgenic mouse brain. Neurobiol. Aging 1995, 16, 685-699.

90. Kumar-Singh, S.; Dewachter, I.; Moechars, D.; Lubke, U.; De Jonghe, C.; Ceuterick, C.; Checler, F.; Naidu, A.; Cordell, B.; Cras, P.; Van Broeckhoven, C.; Van Leuven, F. Behavioral disturbances without amyloid deposits in mice overexpressing human amyloid precursor protein with Flemish (A692G) or Dutch (E693Q) mutation. Neurobiol Dis. 2000, 7, 9-22.

91. Herzig, M.C.; Winkler, D.T.; Burgermeister, P.; Pfeifer, M.; Kohler, E.; Schmidt, S.D.; Danner, S.; Abramowski, D.; Sturchler-Pierrat, C.; Burki, K.; van Duinen, S.G.; Maat-Schieman, M.L.C.; Staufenbiel, M.; Mathews, P.M.; Jucker, M. A beta is targeted to the vasculature in a mouse model of hereditary cerebral hemorrhage with amyloidosis. Nat. Neurosci. 2004, 7, 954-960.

92. Davis, J.; Xu, F.; Deane, R.; Romanov, G.; Previti, M.L.; Zeigler, K.; Zlokovic, B.V.; Van Nostrand, W.E. Early-onset and robust cerebral microvascular accumulation of amyloid betaprotein in transgenic mice expressing low levels of a vasculotropic Dutch/Iowa mutant form of amyloid beta-protein precursor. J. Biol. Chem. 2004, 279, 20296-20306.

93. Miao, J.; Xu, F.; Davis, J.; Otte-Holler, I.; Verbeek, M.M.; Van Nostrand, W.E. Cerebral microvascular $A ß$ protein deposition induces vascular degeneration and neuroinflammation in 
transgenic mice expressing human vasculotropic mutant AßPP. Am. J. Pathol. 2005, 167, 505-515.

94. Hsiao, K.; Chapman, P.; Nilsen, S.; Eckman, C.; Harigaya, Y.; Younkin, S.; Yang, F.; Cole, G. Correlative memory deficits, Abeta elevation, and amyloid plaques in transgenic mice. Science 1996, 274, 99-102.

95. Sturchler-Pierrat, C.; Abramowski, D.; Duke, M.; Wiederhold, K.H.; Mistl, C.; Rothacher, S.; Ledermann, B.; Burki, K.; Frey, P.; Paganetti, P.A.; Waridel, C.; Calhoun, M.E.; Jucker, M.; Probst, A.; Staufenbiel, M.; Sommer, B. Two amyloid precursor protein transgenic mouse models with Alzheimer disease-like pathology. Proc. Natl. Acad. Sci. U.S.A 1997, 94, 1328713292.

96. Domnitz, S.B.; Robbins, E.M.; Hoang, A.W.; Garcia-Alloza, M.; Hyman, B.T.; Rebeck, G.W.; Greenberg, S.M.; Bacskai, B.J.; Frosch, M.P. Progression of cerebral amyloid angiopathy in transgenic mouse models of Alzheimer disease. J. Neuropathol. Exp. Neurol. 2005, 64, 588-594.

97. Borchelt, D.R.; Ratovitski, T.; vanLare, J.; Lee, M.K.; Gonzales, V.; Jenkins, N.A.; Copeland, N.G.; Price, D.L.; Sisodia, S.S. Accelerated amyloid deposition in the brains of transgenic mice coexpressing mutant presenilin 1 and amyloid precursor proteins. Neuron 1997, 19, 939-945.

98. Holcomb, L.; Gordon, M.N.; McGowan, E.; Yu, X.; Benkovic, S.; Jantzen, P.; Wright, K.; Saad, I.; Mueller, R.; Morgan, D.; Sanders, S.; Zehr, C.; O'Campo, K.; Hardy, J.; Prada, C.M.; Eckman, C.; Younkin, S.; Hsiao, K.; Duff, K. Accelerated Alzheimer-type phenotype in transgenic mice carrying both mutant amyloid precursor protein and presenilin 1 transgenes. Nat. Med. 1998, 4, 97-100.

99. Kumar-Singh, S.; Pirici, D.; McGowan, E.; Serneels, S.; Ceuterick, C.; Hardy, J.; Duff, K.; Dickson, D.; Van Broeckhoven, C. Dense core plaques in Tg2576 and PSAPP mouse models of Alzheimer's disease are centered on vessel walls. Am J Pathol 2005, 167, 527-543.

100. McGowan, E.; Pickford, F.; Kim, J.; Onstead, L.; Eriksen, J.; Yu, C.; Skipper, L.; Murphy, M.P.; Beard, J.; Das, P.; Jansen, K.; Delucia, M.; Lin, W.L.; Dolios, G.; Wang, R.; Eckman, C.B.; Dickson, D.W.; Hutton, M.; Hardy, J.; Golde, T. Abeta42 is essential for parenchymal and vascular amyloid deposition in mice. Neuron. 2005, 47, 191-199.

101. Snyder, S.W.; Ladror, U.S.; Wade, W.S.; Wang, G.T.; Barrett, L.W.; Matayoshi, E.D.; Huffaker, H.J.; Krafft, G.A.; Holzman, T.F. Amyloid-Beta Aggregation - Selective-Inhibition of Aggregation in Mixtures of Amyloid with Different Chain Lengths. Biophys. J. 1994, 67, 1216-1228.

102. Kumar-Singh, S.; De Jonghe, C.; Cruts, M.; Kleinert, R.; Wang, R.; Mercken, M.; De Strooper, B.; Vanderstichele, H.; Lofgren, A.; Vanderhoeven, I.; Backhovens, H.; Vanmechelen, E.; Kroisel, P.M.; Van Broeckhoven, C. Nonfibrillar diffuse amyloid deposition due to a gamma(42)-secretase site mutation points to an essential role for N-truncated abeta(42) in Alzheimer's disease. Hum. Mol. Genet. 2000, 9, 2589-2598.

103. Ancolio, K.; Dumanchin, C.; Barelli, H.; Warter, J.M.; Brice, A.; Campion, D.; Frebourg, T.; Checler, F. Unusual phenotypic alteration of beta amyloid precursor protein (APP) maturation by a new Val-715 -> Met APP-770 mutation responsible for probable early-onset Alzheimer's disease. Proc. Natl.Acad. Sci. U.S.A. 1999, 96, 4119-4124. 
104. De Jonghe, C.; Esselens, C.; Kumar-Singh, S.; Craessaerts, K.; Serneels, S.; Checler, F.; Annaert, W.; Van Broeckhoven, C.; De Strooper, B. Pathogenic APP mutations near the gammasecretase cleavage site differentially affect Abeta secretion and APP C-terminal fragment stability. Hum. Mol. Genet. 2001, 10, 1665-1671.

105. Strobel, G.; Davies, P.; Robakis, N.K.; Iwatsubo, T.; Lee, H.G.; Nuno-Mura, A.; Perry, G.; Smith, M.A.; Zheng, H.; De Strooper, B.; Shen, J.; Saura, C.A.; Golde, T.; Hass, M.; Yankner, B.; Marambaud, P.; Checler, F.; Kopan, R.; Tanzi, R.; Neve, R.; Davies, P.; Marchesi, V.; De Strooper, B.; Tanzi, R.; Van Leuven, F.; Pimplikar, S.W.; Tanzi, R.; Kumar-Singh, S. Alzheimer research forum discussion: Gain or loss of function - Time to shake up assumptions on gammasecretase in Alzheimer disease? J. Alzheimers Dis. 2007, 11, 399-416.

106. Mucke, L.; Masliah, E.; Yu, G.Q.; Mallory, M.; Rockenstein, E.M.; Tatsuno, G.; Hu, K.; Kholodenko, D.; Johnson-Wood, K.; McConlogue, L. High-level neuronal expression of abeta 142 in wild-type human amyloid protein precursor transgenic mice: synaptotoxicity without plaque formation. J. Neurosci. 2000, 20, 4050-4058.

107. Wang, R.; Wang, B.; He, W.; Zheng, H. Wild-type presenilin 1 protects against Alzheimer's disease mutation-induced amyloid pathology. J Biol. Chem. 2006, 281, 15330-15336.

108. Deng, Y.; Tarassishin, L.; Kallhoff, V.; Peethumnongsin, E.; Wu, L.; Li, Y.M.; Zheng, H. Deletion of presenilin 1 hydrophilic loop sequence leads to impaired gamma-secretase activity and exacerbated amyloid pathology. J. Neurosci. 2006, 26, 3845-3854.

109. Wyss-Coray, T.; Loike, J.D.; Brionne, T.C.; Lu, E.; Anankov, R.; Yan, F.; Silverstein, S.C.; Husemann, J. Adult mouse astrocytes degrade amyloid-beta in vitro and in situ. Nat. Med. 2003, 9, 453-457.

110. Saido, T.C.; Iwata, N. Metabolism of amyloid beta peptide and pathogenesis of Alzheimer's disease. Towards presymptomatic diagnosis, prevention and therapy. Neurosci. Res. 2006, 54, 235-253.

111. Farris, W.; Schutz, S.G.; Cirrito, J.R.; Shankar, G.M.; Sun, X.; George, A.; Leissring, M.A.; Walsh, D.M.; Qiu, W.Q.; Holtzman, D.M.; Selkoe, D.J. Loss of neprilysin function promotes amyloid plaque formation and causes cerebral amyloid angiopathy. Am. J. Pathol. 2007, 171, 241-251.

112. Meyer-Luehmann, M.; Stalder, M.; Herzig, M.C.; Kaeser, S.A.; Kohler, E.; Pfeifer, M.; Boncristiano, S.; Mathews, P.M.; Mercken, M.; Abramowski, D.; Staufenbiel, M.; Jucker, M. Extracellular amyloid formation and associated pathology in neural grafts. Nat. Neurosci. 2003, 6, 370-377.

113. Shibata, M.; Yamada, S.; Kumar, S.R.; Calero, M.; Bading, J.; Frangione, B.; Holtzman, D.M.; Miller, C.A.; Strickland, D.K.; Ghiso, J.; Zlokovic, B.V. Clearance of Alzheimer's amyloid-ss(140) peptide from brain by LDL receptor-related protein-1 at the blood-brain barrier. J. Clin. Invest. 2000, 106, 1489-1499.

114. Calhoun, M.E.; Burgermeister, P.; Phinney, A.L.; Stalder, M.; Tolnay, M.; Wiederhold, K.H.; Abramowski, D.; Sturchler-Pierrat, C.; Sommer, B.; Staufenbiel, M.; Jucker, M. Neuronal overexpression of mutant amyloid precursor protein results in prominent deposition of cerebrovascular amyloid. Proc. Natl. Acad. Sci. U.S.A 1999, 96, 14088-14093. 
115. Kida, S.; Pantazis, A.; Weller, R.O. CSF drains directly from the subarachnoid space into nasal lymphatics in the rat. Anatomy, histology and immunological significance. Neuropathol.Appl.Neurobiol 1993, 19, 480-488.

116. Wang, Z.; Wu, D.; Vinters, H.V. Hypoxia and reoxygenation of brain microvascular smooth muscle cells in vitro: cellular responses and expression of cerebral amyloid angiopathyassociated proteins. APMIS 2002, 110, 423-434.

117. Miyakawa, T.; Shimoji, A.; Kuramoto, R.; Higuchi, Y. The relationship between senile plaques and cerebral blood vessels in Alzheimer's disease and senile dementia. Morphological mechanism of senile plaque production. Virchows Arch. B. Cell Pathol. Incl. Mol. Pathol. 1982, 40, 121-129.

118. Pirici, D.; Van Broeckhoven, C.; Kumar-Singh, S. Animal models of dementia. De Deyn, P. P and Van Dam, D. Neuromethods. Humana Press Inc., Totowa NJ. 2009.

119. Gravina, S.A.; Ho, L.; Eckman, C.B.; Long, K.E.; Otvos, L.; Younkin, L.H.; Suzuki, N.; Younkin, S.G. Amyloid beta protein (A beta) in Alzheimer's disease brain. Biochemical and immunocytochemical analysis with antibodies specific for forms ending at A beta 40 or A beta 42(43). J. Biol. Chem. 1995, 270, 7013-7016.

120. Iwatsubo, T.; Saido, T.C.; Mann, D.M.; Lee, V.M.; Trojanowski, J.Q. Full-length amyloid-beta (1-42(43)) and amino-terminally modified and truncated amyloid-beta 42(43) deposit in diffuse plaques. Am. J. Pathol. 1996, 149, 1823-1830.

121. McGowan, E.; Sanders, S.; Iwatsubo, T.; Takeuchi, A.; Saido, T.; Zehr, C.; Yu, X.; Uljon, S.; Wang, R.; Mann, D.; Dickson, D.; Duff, K. Amyloid phenotype characterization of transgenic mice overexpressing both mutant amyloid precursor protein and mutant presenilin 1 transgenes. Neurobiol. Dis. 1999, 6, 231-244.

122. Shin, R.W.; Ogino, K.; Kondo, A.; Saido, T.C.; Trojanowski, J.Q.; Kitamoto, T.; Tateishi, J. Amyloid beta-protein (Abeta) 1-40 but not Abeta1-42 contributes to the experimental formation of Alzheimer disease amyloid fibrils in rat brain. J. Neurosci. 1997, 17, 8187-8193.

123. Strittmatter, W.J.; Weisgraber, K.H.; Huang, D.; Dong, L.-M.; Salvesen, G.S.; Pericak-Vance, M.; Schmechel, D.; Saunders, A.M.; Goldgaber, D.; Roses, A.D. Binding of human apolipoprotein $\mathrm{E}$ to synthetic amymloid $\beta$ peptide: Isoform-specific effects and implications for late-onset Alzheimer disease. Proc. Natl. Acad. Sci. USA 1993, 90, 8098-8102.

124. Holtzman, D.M.; Bales, K.R.; Tenkova, T.; Fagan, A.M.; Parsadanian, M.; Sartorius, L.J.; Mackey, B.; Olney, J.; McKeel, D.; Wozniak, D.; Paul, S.M. Apolipoprotein E isoformdependent amyloid deposition and neuritic degeneration in a mouse model of Alzheimer's disease. Proc. Natl. Acad. Sci. USA 2000, 97, 2892-2897.

125. Mann, D.M.; Iwatsubo, T.; Pickering-Brown, S.M.; Owen, F.; Saido, T.C.; Perry, R.H. Preferential deposition of amyloid beta protein (Abeta) in the form Abeta40 in Alzheimer's disease is associated with a gene dosage effect of the apolipoprotein E E4 allele. Neurosci. Lett. 1997, 221, 81-84.

126. Winkler, D.T.; Bondolfi, L.; Herzig, M.C.; Jann, L.; Calhoun, M.E.; Wiederhold, K.H.; Tolnay, M.; Staufenbiel, M.; Jucker, M. Spontaneous hemorrhagic stroke in a mouse model of cerebral amyloid angiopathy. J. Neurosci. 2001, 21, 1619-1627. 
127. Wyss-Coray, T.; Lin, C.; Sanan, D.A.; Mucke, L.; Masliah, E. Chronic overproduction of transforming growth factor-betal by astrocytes promotes Alzheimer's disease-like microvascular degeneration in transgenic mice. Am. J. Pathol. 2000, 156, 139-150.

128. Schenk, D.; Barbour, R.; Dunn, W.; Gordon, G.; Grajeda, H.; Guido, T.; Hu, K.; Huang, J.; Johnson-Wood, K.; Khan, K.; Kholodenko, D.; Lee, M.; Liao, Z.; Lieberburg, I.; Motter, R.; Mutter, L.; Soriano, F.; Shopp, G.; Vasquez, N.; Vandevert, C.; Walker, S.; Wogulis, M.; Yednock, T.; Games, D.; Seubert, P. Immunization with amyloid-beta attenuates Alzheimerdisease-like pathology in the PDAPP mouse [see comments]. Nature 1999, 400, 173-177.

129. Janus, C.; Pearson, J.; McLaurin, J.; Mathews, P.M.; Jiang, Y.; Schmidt, S.D.; Chishti, M.A.; Horne, P.; Heslin, D.; French, J.; Mount, H.T.; Nixon, R.A.; Mercken, M.; Bergeron, C.; Fraser, P.E.; George-Hyslop, P.; Westaway, D. A beta peptide immunization reduces behavioural impairment and plaques in a model of Alzheimer's disease. Nature 2000, 408, 979-982.

130. DeMattos, R.B.; Bales, K.R.; Cummins, D.J.; Paul, S.M.; Holtzman, D.M. Brain to plasma amyloid-beta efflux: a measure of brain amyloid burden in a mouse model of Alzheimer's disease. Science 2002, 295, 2264-2267.

131. Matsuoka, Y.; Saito, M.; LaFrancois, J.; Saito, M.; Gaynor, K.; Olm, V.; Wang, L.L.; Casey, E.; Lu, Y.F.; Shiratori, C.; Lemere, C.; Duff, K. Novel therapeutic approach for the treatment of Alzheimer's disease by peripheral administration of agents with an affinity to beta-amyloid. $J$. Neurosci. 2003, 23, 29-33.

132. Deane, R.; Du, Y.S.; Submamaryan, R.K.; Larue, B.; Jovanovic, S.; Hogg, E.; Welch, D.; Manness, L.; Lin, C.; Yu, J.; Zhu, H.; Ghiso, J.; Frangione, B.; Stern, A.; Schmidt, A.M.; Armstrong, D.L.; Arnold, B.; Liliensiek, B.; Nawroth, P.; Hofman, F.; Kindy, M.; Stern, D.; Zlokovic, B. RAGE mediates amyloid-beta peptide transport across the blood-brain barrier and accumulation in brain. Nat. Med. 2003, 9, 907-913.

133. Dickstein, D.L.; Biron, K.E.; Ujiie, M.; Pfeifer, C.G.; Jeffries, A.R.; Jefferies, W.A. Abeta peptide immunization restores blood-brain barrier integrity in Alzheimer disease. FASEB J. 2006, 20, 426-433.

134. Ferrer, I.; Boada, R.M.; Sanchez Guerra, M.L.; Rey, M.J.; Costa-Jussa, F. Neuropathology and pathogenesis of encephalitis following amyloid-beta immunization in Alzheimer's disease. Brain Pathol. 2004, 14, 11-20.

135. Pfeifer, M.; Boncristiano, S.; Bondolfi, L.; Stalder, A.; Deller, T.; Staufenbiel, M.; Mathews, P.M.; Jucker, M. Cerebral hemorrhage after passive anti-Abeta immunotherapy. Science. 2002, 298, 1379.

136. Hock, C.; Konietzko, U.; Streffer, J.R.; Tracy, J.; Signorell, A.; Muller-Tillmanns, B.; Lemke, U.; Henke, K.; Moritz, E.; Garcia, E.; Wollmer, M.A.; Umbricht, D.; de Quervain, D.J.; Hofmann, M.; Maddalena, A.; Papassotiropoulos, A.; Nitsch, R.M. Antibodies against betaamyloid slow cognitive decline in Alzheimer's disease. Neuron 2003, 38, 547-554.

(C) 2009 by the authors; licensee Molecular Diversity Preservation International, Basel, Switzerland. This article is an open-access article distributed under the terms and conditions of the Creative Commons Attribution license (http://creativecommons.org/licenses/by/3.0/). 